Vol. 2 No. 2 (2019)

\title{
PELUANG DAN TANTANGAN DIPLOMASI BUDAYA TABOT BAGI PROVINSI BENGKULU
}

\author{
Muhnizar Siagian $^{1} \&$ Indra Kusumawardhana ${ }^{2}$ \\ ${ }^{1}$ Universitas Sebelas Maret \\ muhnizar.siagian@staff.uns.ac.id \\ ${ }^{2}$ Universitas Pertamina \\ indrakusumawardhana@gmail.com
}

Doi:

\begin{abstract}
From 1 to 10 Muharam, Tabot Festival was held in Bengkulu. Historically speaking, Tabot is a ceremony or a ritual which was brought by Indian labor in Britain Colonialization Era. Since 1990, Tabot was officially became an annual event held in Bengkulu Province. Tabot as tradition itself is a religious and cultural expression of Islam Syiah which came from a Karbala Tragedy, when the grandchild of Nabi Muhammad, Imam Husein, was murdered. For Bengkulu Province itself, the tradition is able to become an opportunity for cultural diplomacy. The similarity of identity in case of religious and cultural expression to commemorate Karbala Tragedy is a potential material that can be processed by the actor of cultural diplomacy to increase the tourism in Bengkulu. The purpose of this journal is to researching about the cultural diplomacy opportunity of Tabot with multitrack diplomacy between the unity of Bengkulu Province government and the citizen sector which in this case is Tabot family, Tabot art and cultural activist who wanted attention from Islam Syiah follower in other country. However, the internal challenge is a group with puritanism and fundamentalism Islam increasing the sentiment campaign for Islam Syiah and labeling Tabot Festival as Bid'ah and Syirik practice. This research use descriptive-analytical method with building a conceptual framework of cultural diplomacy and multitrack diplomacy.
\end{abstract}

Keywords: Tabot, Cultural Diplomacy., Multitrack Diplomacy.

\begin{abstract}
Abstrak
Tanggal 1 hingga 10 Muharam, di Bengkulu diadakan Festival Tabot. Sejarah mencatat Tabot merupakan upacara dan ritual yang dibawa oleh pekerja dari India di jaman kolonialisme Inggris. Sejak tahun 1990 Tabot resmi menjadi festival tahunan Provinsi Bengkulu. Tradisi Tabot merupakan ekspresi religius dan kebudayaan Islam Syiah yang berangkat dari Tragedi Karbala yaitu dibunuhnya Imam Husein, cucu dari Nabi Muhammad. Bagi Provinsi Bengkulu, tradisi ini bisa menjadi potensi peluang bagi diplomasi kebudayaan. Kesamaan identitas dalam hal ekspresi religius dan kebudayaan untuk memperingati Tragedi Karbala bisa menjadi material yang potensial diolah bagi aktor yang menjalankan diplomasi kebudayaan untuk meningkatkan pariwisata di Bengkulu. Jurnal ini berupaya untuk meneliti mengenai peluang diplomasi budaya Tabot dengan
\end{abstract}


diplomasi multi jalur antara kesatuan pemerintah Provinsi Bengkulu dan sektor warga negara dalam hal ini keluarga Tabot, pegiat seni dan kebudayaan Tabot yang ingin mendapat atensi dari penganut Islam Syiah di berbagai negara Namun tantangannya di dalam negeri, kelompok dengan pandangan agama Islam yang puritan dan fundamental semakin meningkatkan kampanye sentimen terhadap Islam Syiah dan melabeli festival Tabot sebagai praktek bid'ah dan syirik. Penelitian ini menggunakan metode deskriptifanalitis dengan membangun kerangka konseptual diplomasi budaya dan multijalur diplomasi.

\section{Kata kunci: Tabot, Diplomasi Kebudayaan., Multijalur Diplomasi.}

\section{Pendahuluan}

Festival Tabot merupakan festival tahunan yang diadakan di Kota Bengkulu, ibukota dari Provinsi Bengkulu. Sejak awal 1990, Festival Tabot sudah menjadi agenda rutin Provinsi Bengkulu yang diadakan dari tanggal 1 hingga puncaknya pada tanggal 10 Muharam. Festival Tabot dalam sejarahnya ditujukan untuk memperingati Tragedi Karbala, yaitu tragedi terbunuhnya Imam Hussein dalam sejarah panjang kekerasan politik kekuasaan di dalam internal Islam.

Tabot berasal dari kata Tabut yang artinya kotak kayu atau peti yang berisikan Kitab Taurat Bani Israil. Ketika masa kolonialisme Inggris di Bengkulu, Inggris ingin membangun Benteng Malborough pada tahun 1713-1719 (Endang, 2014,49). Pada saat itulah, para pekerja dibawa Inggris dari Madras dan Benggali India, karena saat itu, Inggris juga menjajah kawasan India. Para pekerja inilah yang menjadi asal muasal Festival Tabot di Bengkulu

Para pekerja ini menganut Islam Syiah, meski hari ini di Bengkulu mayoritas muslim sudah Sunni, Festival Tabot tetap menjadi agenda tahunan provinsi Bengkulu. Festival Tabot erat sekali hubungannya dengan Islam Syiah, yang menempatkan sangat penting untuk berduka dan memperingati Tragedi
Karbala dengan berbagai kegiatan. Tidak hanya di Bengkulu, di berbagai belahan dunia, berbagai perayaan, festival dan ritual dilakukan untuk mengenang Tragedi Karbala. Di Indonesia, selain di Bengkulu, kebudayaan Tabot juga terdapat di Pariaman Sumatera Barat dengan nama Tabuik.

Ditandai dengan ritual "mengambil tanah" pada tanggal 1 Muharam dan berbagai agenda kebudayaan seperti Festival Dhol, Mengarak Jari-Jari yang terbuat dari bamboo, Festival TelongTelong dan Ikan-Ikan serta berbagai taritarian dan di malam terakhir disebut dengan Malam Tabot Besanding, yaitu tabot dipamerkan pada malam terakhir. Semua rangkaian festival ditutup dengan "Tabot Tebuang", dibuangnya bangunan Tabot yang sudah dipamerkan ke dua tempat, yaitu daerah Karbala dan Pantai Panjang.

Tabot dengan berbagai agendanya yang diadakan pada 1 hingga 10 Muharam merupakan objek kebudayaan potensial yang bisa dimanfaatkan dalam praktek diplomasi kebudayaan. Potensial karena hingga hari ini belum tergarap dengan maksimal karena berbagai faktor. Masih minimnya kunjungan wisatawan asing pada Festival Tabot merupakan 
salah satu bukti festival ini belum digarap dengan optimal.

Namun selain peluang, terdapat tantangan terhadap Festival Tabot yang memang secara historis berasal dari Islam-Syiah. Tantangan tersebut adalah sentimen yang semakin menguat terhadap Islam Syiah di Indonesia, yang tentu berdampak langsung pada Festival Tabot dan misi Pemerintah Bengkulu untuk meningkatkan kunjungan wisatawan asing dengan jalan diplomasi kebudayaan dan diplomasi multijalur. Jurnal ini akan fokus pada peluang dan tantangan diplomasi kebudayaan yang dilakukan oleh pemerintah provinsi Bengkulu sebagai bagian dari diplomasi Indonesia melalui Tabot.

\section{Metode Penelitian}

Diplomasi yang dulunya merupakan agenda politik tingkat tinggi dengan perwakilan resmi pemerintah yang melakukan interaksi, seiring berkembangnya zaman mengalami demokratisasi aktor dan isu. Aktor dalam hal ini tidak lagi pemerintah dan isu juga tidak lagi soal ekonomi-militer dalam pendekatan Hubungan Internasional yang klasik. Dalam kerangka konseptual pada penelitian ini, penulis ingin membangun satu kerangka konseptual yang saling melengkapi dan membentuk kerangka antara diplomasi budaya dan diplomasi multijalur. Beberapa konsep ini membantu peneliti untuk membangun kerangka konseptual yang utuh untuk membedah penelitian yang sedang dilakukan.

Diplomasi budaya, menurut Milton Cumming (dalam Kim H.J 2011,11) adalah interaksi dalam hal pertukaran ide, informasi kesenian, dan berbagai hal dari dari kebudayaan antar negara dan rakyatnya, hal ini mengisyaratkan diplomasi budaya sebagai aktivitas untuk memperkenalkan budaya sebuah negara kepada negara dan warga negara lain. Gienow dan Hecht $(2010,13)$ mengartikan diplomasi budaya adalah sebuah kumpulan dari Kebijakan nasional dalam hal pengiriman sampel dari budaya suatu bangsa untuk mendukung dan memajukan tujuan kebijakan luar negeri. Budaya merupakan unsur yang sangat vital dalam diplomasi kebudayaan pasca perang dingin berakhir, dikarenakan selama perang dingin isu isu ekonomi, militer dan ideologi sangat mendominasi perbincangan dalam praktek dan studi hubungan internasional. Definisi tersebut juga dapat diinterpretasikan sebagai setiap kebijakan sebuah negara yang dirancang untuk mendorong opini publik untuk memengaruhi pemerintah asing dan sikapnya terhadap negara yang menjalankan diplomasi kebudayaan. Menurut palar (1996, 10) Diplomasi budaya menekankan penggunaan budaya sebagai modal utamanya dan secara natural memberikan ruang untuk partisipasi yang lebih luas. Diplomasi budaya sejatinya merupakan bagian dari diplomasi publik. Diplomasi budaya merupakan poros utama dari diplomasi publik untuk mempromosikan kebudayaan (Regina, 2016. 234).

Dalam hal diplomasi budaya, tetap ada kepentingan nasional yang ingin dicapai dari pelaku diplomasi budaya. Kepentingan nasional didefinisikan sebagai tujuan mendasar serta faktor paling menentukan yang memandu para pembuat keputusan dalam merumuskan politik luar negeri. Kepentingan nasional merupakan konsepsi yang sangat umum tetapi merupakan unsur yang menjadi 
kebutuhan sangat vital bagi negara (Jack diao, Olton, 1999: 7).

Dalam penelitian ini, penulis ingin mengajukan diplomasi multijalur sebagai jalur diplomasi yang terdiri dari 9 aktor penunjang diplomasi publik.

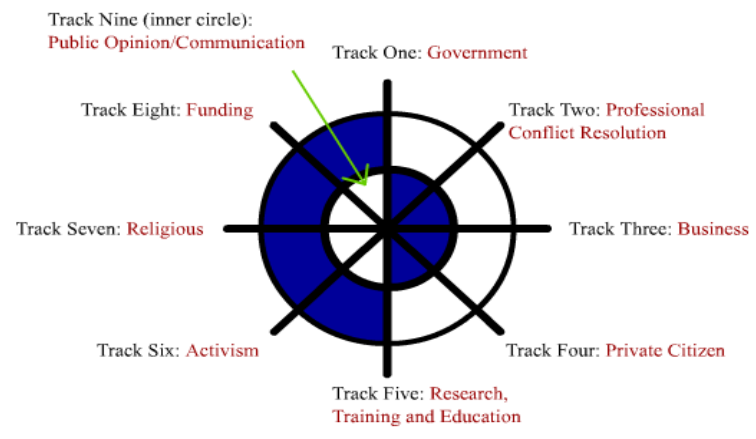

(Diplomasi Multijalur menurut Mcdonald dan Diamond)

Aktor dalam diplomasi multijalur yang dijelaskan oleh Mcdonald dan Diamond (1996) dalam penelitian ini adalah pada jalur pertama dan keempat. Pemerintah Provinsi Bengkulu sebagai penanggung jawab Festival Tabot yang membuka ruang kepada private citizen yang berperan melaksanakan praktek diplomasi secara tidak resmi seperti turut serta dalam program kegiatan pertukaran sipil, baik dalam kerangka pendidikan, budaya, kesehatan dan sebagainya. Dalam hal ini, fokus penelitian pada aktor Pemerintah Provinsi Bengkulu dan warga negara yaitu para keluarga Tabot, pegiat kesenian dan kebudayaan Tabot di Bengkulu. Sasarannya yaitu kelompok agama dan kepercayaan, dalam hal ini penganut Islam Syiah di berbagai belahan dunia.

\section{Pembahasan}

\subsection{Peluang Diplomasi Budaya melalui Tabot}

Festival Tabot di Bengkulu yang erat kaitannya dengan pemeluk agama Islam
Syiah merupakan sebuah peluang diplomasi budaya yang potensial untuk digarap dengan serius oleh Pemerintah Provinsi Bengkulu. Tabot yang sejatinya berasal dari tradisi Islam Syiah untuk memperingati dibunuhnya Imam Hussein, cucu Nabi Muhammad dalam Tragedi Karbala. Bahkan di Bengkulu, tempat pembuangan Tabot di hari terakhir 10 Muharam merupakan komplek pekuburan yang dinamakan Karbala, sama seperti nama tempat di Irak yang menjadi saksi bisu peristiwa dibunuhnya Imam Husein dalam Tragedi Karbala.

Diplomasi budaya kerap berhubungan dengan identitas. Ada titik temu identitas antara keluarga, pelaku seni dan kebudayaan tabot di Bengkulu dan para pemeluk agama Islam Syiah. Titik temunya yaitu kedua belah pihak sama sama menganggap penting untuk memperingati Tragedi Karbala. Jika di Timur Tengah untuk memperingati Tragedi Karbala terkenal dengan peringatan Asyura dan Arbain, di Bengkulu dikenal dengan nama Festival Tabot.

Hari Asyura merupakan puncak peringatan Tragedi Karbala, yaitu tragedi dibunuhnya Imam Husain oleh pasukan dinasti Bani Umayyah pimpinan Yazid bin Muawiyah bin Abi Sufyan di Padang Karbala pada tanggal 10 Muharam tahun $61 \mathrm{H}$ (Muhammad, 2015). Tercatat jutaan pemeluk agama Islam Syiah membanjiri Karbala untuk memperingati Tragedi karbala. 40 Hari setelah diperingati Tragedi Karbala, maka umat Islam Syiah kembali memperingati kematian Imam Husein dengan berjalan menuju Karbala yang disebut dengan "arbaeen walk". Jutaan umat Islam Syiah menganggap peringatan duka ini merupakan puncak dari kesempurnaan Asyura. 
Serupa tapi tak sama, di Bengkulu tepat pada tanggal 1 hingga 10 Muharam diadakan Festival Tabot untuk menghormati Imam Husein dalam Tragedi Karbala. Tabot yang digunakan dalam upacara ini berupa suatu bangunan bertingkat tingkat seperti menara masjid, dengan ukuran yang beragam dan berhiaskan lapisan kertas warna warni. Masyarakat Bengkulu percaya jika perayaan ini tidak diselenggarakan maka akan terjadi musibah atau bencana. Oleh karena itu, Festival Tabot selalu diselenggarakan dengan serangkaian kegiatan yang bersifat ritual dan kolosal. Upacara Tabot ini mengandung aspek ritual dan non-ritual. Aspek ritual hanya boleh dilakukan oleh keluarga keturunan tertentu yang dikenal dengan Kerukunan Keluarga Tabot (KKT) Bengkulu yang dipimpin oleh sesepuh keturunannya langsung, serta memiliki ketentuanketentuan khusus dan norma-norma yang harus ditaati oleh mereka. Sedangkan acara yang mengandung aspek non-ritual dapat diikuti oleh siapa saja.

Rangkaian acara tabot.

1. Ritual Tabot

Pada hari pertama akan ada prosesi Mengambik Tanah (mengambil tanah), lalu pada hari kedua prosesi Duduk Penja (mencuci jari-jari), dan hari ketiga Menjara (mengandun). Acara pada hari keempat dilanjutkan yaitu Meradai (sosialisasi kematian Husein dan wujud kepedulian masyarakat dalam bentuk apapaun), dan hari kelima Arak Penja (mengarak jarijari). Pada hari keenam memasuki prosesi Arak Seroban (mengarak seroban), hari ketujuh Gam (tenang atau berkabung), hari kedelapan
Arak Gedang (taptu akbar), dan hari kesembilan Tabut bersanding dan hari kesepuluh sebagai puncak prosesi Tabot Tebuang (pembuangan Tabut) (Disbudpar Bengkulu, 2019)

2. Lomba Ikan-Ikan

3. Lomba Telong-Telong

4. Lomba Tokok Dhol

5. Lomba Tari Kreasi

6. Pagelaran seni budaya melayu dan berbagai kegiatan lainnya.

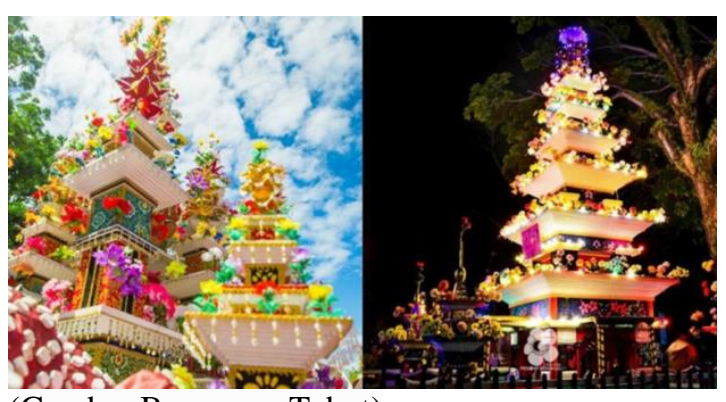

(Gambar Bangunan Tabot)

Dari data yang didapat peneliti ketika melakukan pengambilan data di Dinas Kebudayaan dan Pariwisata Provinsi Bengkulu, wisatawan lokal masih menjadi target utama Festival Tabot. Pada tahun 2019 ada 18.436 wisatawan yang hadir dalam Festival Tabot yang diantaranya hanya 66 wisatawan asing, terdiri dari Singapura, Iran, India, Amerika, Jerman, Inggris, Tanzania, Malaysia, China dan Jepang. Jumlah ini tentu masih jauh dari optimal jika kita melihat data pemeluk agama Islam Syiah di dunia.

Sebagai aktor utama dalam menjalankan diplomasi kebudayaan, Pemerintah provinsi Bengkulu harusnya mampu membaca bahwa ada potensi sasaran diplomasi budaya yang bisa dilakukan Provinsi Bengkulu, yaitu penganut agama Islam Syiah di berbagai negara di belahan dunia. Ada sekitar 173 
Juta Penganut Islam Syiah di dunia yang diantaranya Turki, Yaman, Pakistan, Irak, India dan terbesar ada di Iran. Negara negara tersebut bisa menjadi target dari diplomasi budaya Tabot.

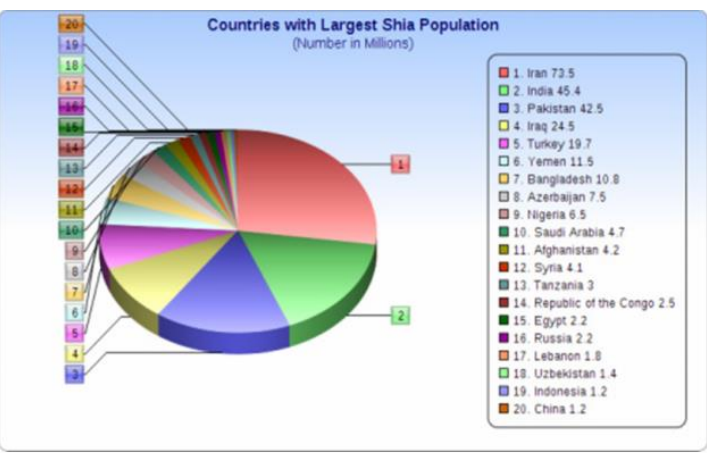

(Data penganut Islam Syiah di Dunia)

Berbagai negara dengan penganut agama Islam Syiah di dunia di atas merupakan sasaran promosi prioritas yang harusnya dituju oleh Pemerintah Provinsi Bengkulu. Peluang-peluang tersebut bisa sebenarnya dimanfaatkan mengingat bagaimana duta besar Iran untuk Indonesia, Valiollah Mohammadi. mengatakan "Saya merasa bangga dengan budaya Bengkulu seperti Tabot yang memiliki akar budaya dari Persia”, dalam sambutannya dalam kunjungan dalam rangka menghadiri festival batik Internasional yang diadakan kota Bengkulu.

Dalam manajemen bisnis pariwisata, Pemerintah provinsi Bengkulu harus mampu membaca berbagai motivasi wisatawan untuk berwisata,salah satunya menurut Michael Hall (2006,i) Religion and spirituality are still among the most common motivations for travel. Hughes dkk (2013) menjelaskan keyakinan agama merupakan motivasi yang membuat wisatawan tertarik pada warisan sejarah, arsitektur, budaya dan hal-hal yang artistic yang berasal dari agama. Menurut
Digance (2003, 1) meskipun ada tren global menuju sekularisasi, dalam beberapa tahun terakhir orang-orang kembali memikirkan perjalanan ke tempat dan rute yang bersifat religius. World Tourism Organisation pada tahun 2014 mencatat antara 300 dan 330 juta orang bepergian karena alasan agama setiap tahun, menghasilkan dampak ekonomi sekitar 18.000 juta dolar.

Dalam industri pariwisata, banyak faktor yang bisa mendatangkan wisatawan salah satunya adalah festival yang berangkat dari ritual dan tradisi. Dalam hal ini, Pemerintah Provinsi Bengkulu harusnya mampu membaca berbagai motivasi orang-orang untuk melakukan wisata, salah satunya adalah motivasi religius dan kebudayaan yang lahir dari kepercayaan agama. Motivasi religius pemeluk agama Islam Syiah sangat meletakkan tempat penting pada perayaan yang menyangkut Imam Husein dan Tragedi Karbala. Sedangkan motivasi kebudayaan untuk melihat ekspresi lain dari perayaan Tragedi Karbala yang berbeda dengan Asyura atau Arbain.

Menurut Timothy dan Boyd $(2003,3)$ di negara-negara di seluruh dunia, agama dan berbagai hal yang terkait dengan agama seperti situs, ritual dan festival, dilihat oleh banyak pemerintah dan penggerak industri pariwisata sebagai bentuk warisan yang bisa menjadi sumber daya yang dapat diubah dan dikomodifikasi untuk konsumsi wisatawan, yang pada gilirannya mendorong tumbuhnya waktu luang dan kegiatan lainnya. Sekretaris Jenderal Organisasi Pariwisata Dunia (UNWTO) Taleb Rifai (2015) dalam antusiasmenya terhadap pariwisata religius, menyarankan bahwa 'wisata religius dapat menjadi salah satu alat 
paling efektif untuk mendorong pembangunan yang inklusif dan berkelanjutan'. Dengan demikian, tiga manfaat utama dari wisata religi diidentifikasi:

1. Wisata religius meningkatkan kesadaran umat manusia warisan bersama dan akan menggerakkan pelestarian terhadap hal tersebut.

2. Dapat berkontribusi untuk pembangunan lokal.

3. Wisata religius dapat membangun pemahaman budaya.

Namun pada saat bersamaan, UNWTO menyoroti apa mereka menyebutnya 'tantangan penting' yang meliputi:

1. Pelestarian situs-situs dan monumen keagamaan.

2. Menjunjung tinggi rasa hormat terhadap tradisi lokal dan praktik keagamaan.

3. Pengembangan yang inklusif terhadap masyarakat lokal.

Negara-negara dengan pemeluk Islam Syiah di dunia harusnya menjadi target diplomasi kebudayaan dari Provinsi Bengkulu dengan memperkenalkan tradisi dan Festival Tabot. Pemerintah Provinsi Bengkulu bisa menjalankan kerjasama antar pemerintah lokal antara Provinsi Bengkulu dan Pemerintah Provinsi di berbagai negara di Iran,Irak, India, Pakistan dan Turki dan berbagai negara lainnya dengan pemeluk Islam Syiah yang populasinya besar. Selain strategi tersebut, Pemerintah Provinsi Bengkulu juga bisa memanfaatkan kedutaankedutaan Indonesia yang ada di negara dengan pemeluk Islam Syiah untuk menyampaikan bahwa di Bengkulu, Tragedi Karbala dan Hari Asyura juga diperingati dengan Festival Tabot. Strategi ini tidak lain untuk meningkatkan kunjungan wisatawan asing dalam Festival Tabot. Kunjungan tersebut akan berdampak banyak terhadap pembangunan di Provinsi Bengkulu, termasuk menggerakkan ekonomi dan berkontribusi bagi pembangunan lokal. Selain kepentingan ekonomi, kepentingan membangun pemahaman budaya bersama mengenai ritual dan upacara di Hari Asyura antara penduduk di Bengkulu dan para penganut Islam Syiah di berbagai negara juga menjadi tujuan dari diplomasi budaya.

\subsection{Tantangan Diplomasi Budaya melalui Tabot Bagi Pemerintah Provinsi Bengkulu}

Peluang yang telah dijelaskan di atas sekaligus menjadi tantangan bagi Pemerintah Provinsi Bengkulu dan para keluarga Tabot, seniman dan budayawan yang terlibat dalam Festival Tabot. Tantangan di dalam negeri yaitu menguatnya fundamentalisme Islam yang terus melakukan teror teologis untuk memberi label syirik, bid'ah dan sesat dalam ritual dan Festival Tabot. Di dalam tubuh umat Islam, serangan ini bukan hal baru. Kelompok-kelompok puritan fundamentalisme Islam sebelumnya menyerang kelompok umat Islam yang masih melestarikan budaya, ritual dan berbagai festival dengan sebutan penyakit "TBC" yang menjangkiti umat islam". TBC singkatan dari tahayul, bid'ah chufarat. (Burhaini, 2013, 133-134).

Pada November 2013, terjadi polemik antara seorang ustad yang didukung oleh pengurus Ikatan Masjid Indonesia (IKMI) Bengkulu dengan keluarga Tabot. Polemik tersebut diawali 
dengan khotbah jumat yang disampaikan oleh seorang ustad yang mengatakan bahwa merayakan Tabot bisa merusak akidah umat Islam karena mengandung kesesatan dan syirik, juga merupakan bagian dari religius dan budaya Syiah yang di Indonesia dianggap aliran sesat. Secara lengkap, IKMI menyampaikan "proses ritual Tabot mengandung unsur syirik. Diantaranya proses duduk penja, mengambil tanah, bakar kemenyan di kuburan yang dihormati. Prosesnya banyak yang mengandung syirik. Contoh, mengambil tanah, lalu dibungkus kain, lalu didoakan. Itu bukanlah ajaran Islam. Begitupun dengan ziarah ke makam membawa kemenyan. Ajaran Islam tidak pernah mengajarkan berziarah membakar menyan, kalau memang untuk menghilangkan bau, ya silakan saja pakai obat nyamuk atau parfum," (Nahim Munkar, 2013).

Di Indonesia sendiri, MUI telah memberi edaran untuk mewaspadai masuknya paham Syiah di Indonesia, dengan redaksional lengkap "Mengingat perbedaan-perbedaan pokok antara Syi'ah dan Ahlus Sunnah wal Jama'ah seperti tersebut di atas, terutama mengenai perbedaan tentang "Imamah" (pemerintahan)", Majelis Ulama Indonesia menghimbau kepada umat Islam Indonesia yang berfaham Ahlus Sunnah wal Jama'ah agar meningkatkan kewaspadaan terhadap kemungkinan masuknya faham yang didasarkan atas ajaran Syi'ah" (MUI, 2006). Di tataran masyarakat sipil, sudah terbentuk ANNAS Indonesia, yaitu singkatan dari Aliansi Nasional Anti Syiah yang keras menolak semua yang berbau Syiah di Indonesia. Hal ini ditambah beberapa waktu lalu terjadi pengusiran terhadap penduduk Syiah di sampang, pembubaran peringatan Hari Asyura di berbagai tempat dan berbagai citra buruk dan sentimen terhadap Syiah di Indonesia

Berbagai fenomena di atas memperlihatkan bagaimana fundamentalisme agama Islam semakin menguat dan hal ini tentu membahayakan Festival Tabot yang diadakan di Bengkulu dan secara umum berbagai festival kebudayaan lainnya di berbagai wilayah Indonesia. Tentu kita masih ingat bagaimana akhir 2018, Ritual Sedekah Laut yang rutin diadakan di Bantul dibubarkan sekelompok orang yang meminta Festival Sedekah Laut dibatalkan karena berbau syirik dan musyrik dan bertentangan dengan agama Islam (Pertana, 2018). Di Banyuwangi, Festival Gandrung Sewu yang rutin diadakan pada tahun 2018 sempat ditolak oleh ormas Islam, karena dianggap mengandung kemusyrikan dan dapat mendatangkan bencana di Banyuwangi (Fanani, 2018).

Pemerintah Provinsi Bengkulu, tidak hanya harus fokus untuk menangkap peluang sasaran diplomasi budaya Tabot di luar negeri seperti yang dijelaskan di pembahasan peluang diplomasi budaya Tabot, namun juga di dalam wilayahnya harus terus mengupayakan kesadaran masyarakat akan pentingnya pluralisme, sebuah pandangan untuk toleran dan menghormati keberagaman.

Terdapat 2 hal dalam Pluralisme menurut The New International Webster's Comprehensive Dictionary of The English Language (1996, 972) : pertama, pengakuan bahwa adanya keberagaman kelompok seperti keberagaman yang bercorak ras, agama, suku, aliran, maupun partai dan tetap menjunjung tinggi berbagai keberagaman yang melekat pada 
kelompok-kelompok tersebut. Kedua, dalam hal pemikiran filosofis, bahwa pluralisme merupakan doktrin yang memandang bahwa tidak ada pendapat yang benar atau semua pendapat adalah sama benarnya. Menurut Buya Syafii Maarif $(2015,12)$ pluralitas adalah suatu keanekaragaman yang ada dalam suatu masyarakat dan mengakui bahwa hal yang lain ada di luar kelompoknya. Sedangkan pluralisme bukan sekedar fakta atau keadaan yang bersifat plural akan tetapi merupakan suatu sikap yang mengakui sekaligus menghargai dan menghormati bahkan mengembangkan dan memperkaya keadaan yang bersifat plural.

Pandangan hidup pluralisme pernah ditolak oleh Majelis Ulama Indonesia (MUI) dengan mengeluarkan fatwa haram mengenai pluralisme, liberalisme dan sekularisme pada Juli 2005, karena dianggap bertentangan dengan ajaran Islam dalam hal aqidah dan ibadah. Kelompok puritan dan fundamentalisme Islam hingga hari ini masih mendukung fatwa tersebut dengan menyingkat bahwa umat Islam yang berpandangan plural terjangkit penyakit sipilis (nama penyakit kelamin), singkatan dari sekularisme, pluralisme dan liberalisme. (Carool, 2018 xii).

Berhasilnya diplomasi budaya Tabot secara langsung tentu berhubungan dengan dukungan dari masyarakat sipil di Bengkulu lebih umum di Indonesia. Dukungan tersebut sangat tergantung pada pandangan masyarakat sipil mengenai berbagai keberagaman kebudayaan. Citra baik masyarakat Bengkulu lebih umum Indonesia yang plural harus dipertahankan dan ditingkatkan, di tengah menggejalanya fundamentalisme agama islam yang membahayakan berbagai ritual, festival dan agenda religius dan kebudayaan di Indonesia, terkhusus di Provinsi Bengkulu.

Terlebih tak bisa dielakkan bahwa adanya fakta historis, Tabot merupakan festival dan ritual yang berasal dari penganut Islam Syiah yang meletakkan pentingnya penghormatan terhadap Imam Husein dalam Tragedi Karbala. Secara langsung, semakin menguatnya sentimen terhadap Islam Syiah tentu berpengaruh terhadap pandangan masyarakat sipil mengenai Festival dan Ritual Tabot. Hal itu juga diperparah dengan menguatnya kelompok-kelompok yang menginginkan kembalinya kemurnian Islam yang terus menyerang berbagai festival kebudayaan di Indonesia termasuk Tabot dengan label sesat, syirik, musyrik, sesat dan bid'ah. Jika hal ini terus menguat dan mendapat tempat di ruang ruang publik bukan tidak mungkin, kelompok masyarakat sipil yang mengusung fundamentalisme Islam yang intoleran merupakan hambatan yang bisa membuat citra buruk Bengkulu lebih umum Indonesia dalam berbagai misi diplomasi kebudayaan. Upaya Pemerintah Bengkulu untuk meningkatkan nilai dan pandangan pluralisme di dalam masyarakat tentu berhubungan langsung dengan keberlangsungan, kesuksesan dan meningkatnya kunjungan wisatawan asing terkhusus dengan motif religiuskebudayaan, yaitu para penganut Islam Syiah dari berbagai negara dalam Festival Tabot.

\section{Kesimpulan}

Aspek religius merupakan aspek penting yang menjadi motivasi orang untuk melakukan wisata. Pemerintah Provinsi Bengkulu harus mampu membaca ada peluang besar yang bisa meningkatkan 
kunjungan wisatawan asing dalam Festival tahunan Tabot yang diadakan di Bengkulu. Peluang tersebut adalah pemeluk agama Islam Syiah yang tersebar di berbagai negara seperti Iran, Irak, India, Turki, Pakistan dan negara lainya.

Namun, seperti dua keping mata uang, peluang tersebut sekaligus menjadi tantangan untuk terus melestarikan dan memajukan Festival Tabot yang secara historis memang berasal dari Islam Syiah. Meningkatnya sentimen terhadap Islam Syiah di Indonesia terkhusus di Bengkulu juga teror teologis yang dilakukan oleh kelompok Islam puritan dan fundamental dengan melabeli festival Tabot sebagai perilaku menyimpang dalam agama yaitu syirik, bid'ah dan sesat. Mengupayakan nilai-nilai pluralisme merupakan salah satu solusi untuk menjaga dukungan masyarakat sipil terhadap Festival Tabot. Dalam hal diplomasi budaya Tabot, ada hubungan langsung antara keberhasilan diplomasi Tabot di luar negeri dengan pluralisme di dalam negeri di tubuh di masyarakat sipil di Bengkulu lebih umum Indonesia.

\section{DAFTAR PUSTAKA}

Burhani, Ahmad Najib. (2013). Liberal and Conservative Discourse in the Muhammadiah: The Struggle for The Face of Reformist Islam in Indonesia. Singapura: ISEAS.,hal 133-4.

Diamond, L. \& McDonald, J. (1996) "Multi Track Diplomacy: A Systems Approach to Peace, 3RD edn". Connecticut: Kumarian Press.

Digance Justine (2006). Religious and Secular Pilgrimage. London and New York: Routledge.
Faustin Darwanto, Regina. (2016). Diplomasi Dalam Politik Global. Bandung: Unpar Press., hlm. 234.

Jessica Gienow-Hect C. E and Mark C. Donfried. (2010). "The Model of Cultural Diplomacy : Power Distance and the promise of Civil Society". Searching for A Cultural Diplomacy. New York : Berghann Books., hlm. 18.

Kersten Carool. (2018). Berebut Wacana: Pergulatan Wacana Umat Islam Indonesia Era Reformasi. Bandung. Mizan., hlm. xii.

Kim, Hwajung. (2011). "Cultural Diplomacy as the Means of Soft Power in an Information Age." Institute for Cultural Diplomacy. Accessed at http://www.culturaldiplomacy.org/p df/casestudies/Hwajung_Kim_Cultural_Di plomacy_as_the_Means_of_Soft_P ower_in_the_Information_Age.pdf (March 20, 2016)., hlm. 11.

Manuela Agullar. (1996). "Cultural Diplomacy and Foreign Policy: German -American Relationship 1055-1968". New York: Peter Lang., hlm. 10

Plano C. Jack dan Olton Roy. (1999). Kamus Hubungan Internasional. Bandung: Abardin., hlm. 7

Rifai, T. (2015) Opening Speech, by Secretary-General, World Tourism Organization (UNWTO), at International Conference on Religious Tourism "Fostering sustainable socio-economic development in host communities" 15 June 2015 - Bethlehem, State of Palestine (available at: http:// dtxtq4w60xqpw. cloudfront. net/sites/all/files/pdf/ final_ sg_ 
religious

tourism_bethlehem_15.pdf)

Rocmiatun, Endang. (2014). Tradisi

Tabot Pada Bulan Muharam di

Bengkulu : Paradigma

Dekonstruksi. Jurnal Kebudayaan

dan Sastra Islam UIN Raden Patah

Palembang., hlm. 49.

The New International Webster's Comprehensive Dictionary of The English Language, (1996) Chicago: Trident Press International., hlm. 972

Timothy, Dallen and Daniel Olsen. (2006). "Tourism, Religion and Spiritual Journeys." London and New York: Routledge.

\section{Sumber Online}

http://liputanislam.com/internasional/timu r-tengah/peringatan-hari-asyurajutaan-orang-banjiri-kota-karbala/ diakses pada hari Minggu 13 Oktober 2019 pukul 19.00 WIB

https://www.nahimunkar.org/ramaikhutbah-tentang-tabot-berbausyiah-dan-syirik-di-bengkulu/ diakses pada hari Minggu 13 Oktober 2019 pukul 19.00 WIB

http://mui.or.id/wp-

content/uploads/files/fatwa/06.Faham-Syiah.pdf https://news.detik.com/berita-jawatengah/d-4254941/tradisi-sedekahlaut-bantul-dibubarkan-wargamereka-bilang-syirik diakses pada hari Minggu 13 Oktober 2019 pukul 19.00 WIB

https://news.detik.com/berita-jawatimur/d-4263003/ini-alasan-fpitolak-festival-gandrung-sewu diakses pada hari Minggu 13 Oktober 2019 pukul 19.00 WIB 